\title{
Taxonomic studies of Cryptomonas lundii clade (Cryptophyta: Cryptophyceae) with description of a new species from Vietnam
}

\author{
Evgeniy Gusev $^{1 *}$, Yulia PodunaY ${ }^{2}$, Nikita Martynenko ${ }^{1}$, Natalia Shkurina ${ }^{1}$ \\ \& Maxim KuliKovsKIY ${ }^{1}$
}

\author{
${ }^{1}$ K.A. Timiryazev Institute of Plant Physiology RAS, IPP RAS, 35 Botanicheskaya Street., Moscow, 127276 \\ Russia; *Corresponding authore-mail: algogus@yandex.ru \\ ${ }^{2}$ T. I. Vyazemsky Karadag Scientific Station - Nature Reserve of RAS - Branch of A. O. Kovalevsky Institute of \\ Biology of the Southern Seas of RAS, 24 Nauki Street, Feodosia, 298188 Russia
}

\begin{abstract}
A new species from Vietnam, Cryptomonas vietnamica sp. nov., is described based on morphological and molecular data. Six strains from different habitats were analyzed. Cryptomonas vietnamica is characterized by large cells up to $54 \mu \mathrm{m}$ long, $30 \mu \mathrm{m}$ wide and $20 \mu \mathrm{m}$ thick, flattened in dorso-ventral plane and often twisted. Phylogenetic relationships inferred from nuclear small and large subunit ribosomal DNA sequences show that the new species forms a clade with Cryptomonas lundii, a rare taxon, described from Europe. Cryptomonas lundii is reported for the first time from Russia and second time since its initial description.
\end{abstract}

Key words: Cryptomonas, new species, nuclear SSU and LSU rDNA phylogeny, ITS2 secondary structure, Vietnam, Russia

\section{INTRODUCTION}

Cryptophytes (= cryptomonads) are mostly photoautotrophic, unicellular, biflagellate protists distributed in diverse freshwater, brackish, and marine habitats (HoEF-EMden \& ARChibald 2016). Cryptomonads tend to be quite fragile due to their organic periplast; their numbers may therefore be underestimated in field collections. This feature also makes it difficult to isolate species in a culture. Recent research has shown that even in well-sampled regions and habitats, the true diversity of cryptomonads has not yet been uncovered (VON DER Heyden et al. 2004; Cerino \& Zingone 2006; LANE \& ARChIBALD 2008; Shalchian-TABrizI et al. 2008; BoENIGK et al. 2018).

Cryptomonas Ehrenberg (EHRENBERG 1831) is a genus of cryptomonads with about 70 currently accepted morphospecies which are restricted to freshwater (Hoef-Emden \& MeLKonian 2003). The dimorphic life history of Cryptomonas have resulted in inconsistent systematics, and a lack of species-specific character hampers the identification of species by morphology (HoEf-Emden \& Melkonian 2003). Correct species identification of most Cryptomonas taxa is possible only with molecular characters (HoEF-EMDEN 2007).

The most extensive studies of Cryptomonas diversity and taxonomy have been conducted in Europe, resulting in two comprehensive revisions (HoEF-EMDEN \& Melkonian 2003; Hoef-Emden 2007). Studies in South Korea have revealed the rich flora of the genus Cryptomonas, including four new lineages (unidentified species), but no taxonomic revisions have been made (CHOI et al. 2013). Two species were also reported from China during molecular studies of algae (XIA et al. 2013). No specialized molecular studies of freshwater cryptomonads have been conducted in the tropics. Here, we describe a new species from Vietnam, Cryptomonas vietnamica sp. nov., and also report the presence of a rare species, C. lundii Hoef-Emden et Melkonian, in Russia.

\section{Material ANd Methods}

Samples were collected in Russia and Vietnam. Sample collection in Vietnam took place in the Khanh Hoa and Dong Nai provinces in 2015 and 2018. Samples in Khanh Hoa province were collected from an unnamed sand pit with standing water and a bog pool situated on the Cam Ranh Peninsula in April 2018 (Table 1). In Dong Nai province, three samples were collected in the area of Cat Tien National Park in October 2015, and one was collected from the Ba Hao reservoir, Vinh Cuu district, in May 2018 (Table 1). This area has a tropical monsoon climate. The average annual temperature ranges between 25 and $28^{\circ} \mathrm{C}$, the relative humidity between 80 and 
$94 \%$, the annual precipitation is $1800-2100 \mathrm{~mm}$ and the annual evaporation is $1000-1200 \mathrm{~mm}$. The sample from Russia was collected in Meshchyora National Park in Vladimirskaya oblast in October 2016 (Table 1).

Planktonic samples were collected using a plankton net with a $20-\mu \mathrm{m}$ mesh. Water mineralization and temperature measurements were performed using the Hanna device (HI 9828, Hanna Instruments, Inc., Woonsocket, RI, USA). Strains were isolated and cultures were transferred to the Collection of Algae at Laboratory of Molecular Systematics of Aquatic Plants of K.A. Timiryazev Institute of Plant Physiology Russian Academy of Sciences.

Monoclonal strains were established by examination of micropipetted single cells under an inverted microscope. Non-axenic unialgal cultures were maintained in $\mathrm{WC}$ and Waris-H liquid medium (McFadden \& Melkonian 1986; ANDERSEN 2005) at $10^{\circ} \mathrm{C}$ in a growth chamber with a $12: 12$ $\mathrm{h}$ light:dark photoperiod.

For light microscopical examinations, live cells were immobilized by embedding in ultra-low gelling agarose (Sigma-Aldrich, A4018, USA) and examined by Nomarski differential interference contrast (DIC) with an oil immersion lens (Plan-Apochromat 100x/1.40 Oil DIC M27; microscope Zeiss AxioScope A1; Carl Zeiss AG, Oberkochem, Germany). Cell shape, size, shape of the furrow-gullet system and cell plastids were examined (55 cells). For description, the terminology introduced in HoEF-EMDEN \& MELKONIAN (2003) was used (ventral side corresponds to the opening side of the furrow-gullet system). Light micrographs were taken with an AxioCamERc 5s Rev.2.

Total DNA was extracted from monoclonal cultures using InstaGeneTM Matrix according to the manufacturer's protocol. Fragments of nuclear SSU and LSU rDNA, and ITS2 rDNA were amplified using primers from Choi et al. (2013): 18S CrN1F, 18S 826F, 18S 956R, 18S BRK for nuclear SSU rDNA, crLSU 29F and crLSU 942R for partial nuclear LSU rDNA and crITS_03F and crITS_05R for nuclear ITS2 rDNA. Amplification of all studied fragments was carried out using the premade mix ScreenMix (Evrogen, Russia) for the polymerase chain reaction (PCR). The conditions of amplification for SSU, LSU and ITS2 rDNA fragments were: an initial denaturation of 5 min at $95{ }^{\circ} \mathrm{C}$, followed by 35 cycles at 94 ${ }^{\circ} \mathrm{C}$ for denaturation $(30 \mathrm{~s}), 52{ }^{\circ} \mathrm{C}$ for annealing $(30 \mathrm{~s})$ and 72 ${ }^{\circ} \mathrm{C}$ for extension (50-80 s), and a final extension of $10 \mathrm{~min}$ at $72{ }^{\circ} \mathrm{C}$. The resulting amplicons were visualized by horizontal agarose gel electrophoresis (1.5\%), colored with SYBR Safe (Life Technologies, Carlsbad, CA, USA). Purification of DNA fragments was performed with the ExoSAP-IT kit (Affymetrix, Santa Clara, CA, USA) according to the manufacturer's protocol. SSU rDNA and LSU rDNA fragments were decoded from two sides using forward and reverse PCR primers and the Big Dye system (Applied Biosystems, Foster City, CA, USA), followed by electrophoresis using a Genetic Analyzer 3500 sequencer (Applied Biosystems, Foster City, CA, USA). Sequences were checked manually and assembled using BioEdit v7.1.3 and MegaX (Kumar et al. 2018). Newly determined sequences and GenBank sequences of 46 other cryptomonads from different morphological groups were included in the alignments. Two species (Rhodomonas sp. strain M1480 and Chroomonas sp. strain SAG 980-1) were chosen as outgroup taxa. Sequences were aligned using MAFFT v7 with model EINS-i (КАTOH \& TOH 2010), refined by eye and nonalignable sites were excluded from the analysis. jModelTest 2.1.1 indicated that the GTR model

Table 1. Basic characteristics of the studied localities (Cond. - specific conductance $\left(\mu \mathrm{S} . \mathrm{cm}^{-1}\right), \mathrm{T}-$ temperature $\left.\left({ }^{\circ} \mathrm{C}\right)\right)$ and GenBank accession numbers of the strains.

\begin{tabular}{|c|c|c|c|c|c|c|c|}
\hline Strains & Localities & Coordinates & pH & Cond. & $\mathbf{T}$ & $\begin{array}{l}\text { ITS2-LSU } \\
\text { rDNA }\end{array}$ & SSU rDNA \\
\hline \multicolumn{8}{|c|}{ Vietnam } \\
\hline VN873 & $\begin{array}{l}\text { Old irrigation pond, } \\
\text { Cat Tien National Park, } \\
\text { Dong Nai Province }\end{array}$ & $\begin{array}{l}11^{\circ} 24.386^{\prime} \mathrm{N} \\
107^{\circ} 22.463^{\prime} \mathrm{E}\end{array}$ & 6.2 & 20 & 31 & MT216866 & MT216859 \\
\hline VN874 & $\begin{array}{l}\text { Grass wetlands, Cat } \\
\text { Tien National Park, } \\
\text { Dong Nai Province }\end{array}$ & $\begin{array}{l}11^{\circ} 24.217^{\prime} \mathrm{N} \\
107^{\circ} 22.451^{\prime} \mathrm{E}\end{array}$ & 5.5 & 11 & 29 & MT232230 & MT232228 \\
\hline VN877 & $\begin{array}{l}\text { Stream, Cat Tien Na- } \\
\text { tional Park, Dong Nai } \\
\text { Province }\end{array}$ & $\begin{array}{l}11^{\circ} 24.342^{\prime} \mathrm{N} \\
107^{\circ} 22.442^{\prime} \mathrm{E}\end{array}$ & 5.8 & 20 & 29 & MT232231 & MT232229 \\
\hline VN881 & $\begin{array}{l}\text { Ba Hao reservoir, Dong } \\
\text { Nai Province }\end{array}$ & $\begin{array}{l}11^{\circ} 15.390^{\prime} \mathrm{N} \\
107^{\circ} 04.493^{\prime} \mathrm{E}\end{array}$ & 5.9 & 26 & 33 & MT216868 & MT216861 \\
\hline VN882 & $\begin{array}{l}\text { Bog pool in Cam Ranh } \\
\text { Peninsula, Khanh Hoa } \\
\text { Province }\end{array}$ & $\begin{array}{l}12^{\circ} 4.674^{\prime} \mathrm{N} \\
109^{\circ} 11.220^{\prime} \mathrm{E}\end{array}$ & 5.2 & 80 & 30 & MT216869 & MT216862 \\
\hline VN880 & $\begin{array}{l}\text { Unnamed sandpit in } \\
\text { Cam Ranh Peninsula, } \\
\text { Khanh Hoa Province }\end{array}$ & $\begin{array}{l}12^{\circ} 04.785^{\prime} \mathrm{N} \\
109^{\circ} 11.130^{\prime} \mathrm{E}\end{array}$ & 6.7 & 127 & 35 & MT216867 & MT216860 \\
\hline \multicolumn{8}{|c|}{ Russia } \\
\hline R179 & $\begin{array}{l}\text { Peat bog in Mesh- } \\
\text { chyora National Park, } \\
\text { Vladimirskaya oblast }\end{array}$ & $\begin{array}{l}55^{\circ} 35.077^{\prime} \mathrm{N} \\
40^{\circ} 26.485^{\prime} \mathrm{E}\end{array}$ & 6.3 & 42 & 4.2 & MT216865 & MT216858 \\
\hline
\end{tabular}


of nucleotide substitution, with Gamma (G) distributed rates across sites and a proportion of invariable sites (I), was the most appropriate evolutionary model for SSU rDNA and LSU rDNA alignments individually and in general (PosADA 2006). Finally, we constructed the concatenated SSU + LSU rDNA alignment (2416 nt) of 52 taxa. Phylogenies were constructed based on this model for complete alignment using Bayesian Inference (BI) and Maximum Likelihood (ML) analysis. BI analysis was conducted with MrBayes-3.2.5 (RoNQUIST \& HuELSENBECK 2003). Three "hot" and one "cold" Markov chains were run for $1 \times 10^{6}$ cycles in two repetitions with the selection of each 200th generated tree. Phylogenetic tree and posterior branching probabilities were obtained after discarding the first $25 \%$ to produce estimate parameter models of nucleotide substitutions and likelihood. ML-analysis was performed using the program MegaX (Kumar et al. 2018). The bootstrap analysis with 1,000 replicas was used. Viewing and editing of trees were carried out in the programs FigTree (ver. 1.4.2) and Adobe Photoshop CC (19.0).

Secondary structure prediction. Nuclear ITS2 sequences were folded using the mfold server (http://mfold.rna.albany. edu/?q=mfold/RNA-Folding-Form) (ZuKer 2003) with default values. HOEF-EMDEN (2007) provided a complete RNA secondary structure graph of the nuclear ITS2 rDNA of Cryptomonas sp. M1634, which was used as a template and assisted in inference of common stems, loops, and bulges. The ITS2 sequences were aligned according to secondary structure and were checked for compensatory base changes (CBCs) using 4SALE (SEIBEL et al. 2008).

\section{RESULTS}

Seven strains from the Cryptomonas lundii clade were revealed during studies of freshwater cryptomonads in Russia and Vietnam. Phylogenetic relationships inferred from nuclear SSU and LSU rDNA show the strains are grouped in two clades. The strain from Russia (R179, Fig. 8-9) was grouped with the type $C$. lundii strain CCAC 0107 (=M0850). Strains from Vietnam formed another clade with high statistical support. The cell size and morphology differ from that of Cryptomonas lundii. The Vietnamese strains come from two distant areas. Strains VN873, VN874, VN877 and VN881 were isolated from different localities in Dong Nai Province. The other two strains, VN880 and VN882, were isolated in Khanh Hoa Province, several hundred kilometres to the north. All six have identical LSU, SSU and ITS2 rDNA nucleotide sequences. Comparison of ITS2 secondary structures between strains from Vietnam and $C$. lundii revealed some differences. For ITS2 sequences of $C$. vietnamica (340 nt) and $C$. lundii (355 nt) four-helix structures could be inferred with long third helices. An unpaired U-U was found in Helix II. Three Compensatory Base Changes (CBCs) between two taxa were observed in Helix III, one CBC was found in Helix I and Helix II (Fig. 11).

Below, we describe a new species based on morphology and molecular data.
Cryptomonas vietnamica Gusev, Podunay, Martynenko, Shkurina et Kulikovskiy sp. nov. (Figs 1-7)

Diagnosis: Cells (absolute minimal and maximal values of strain VN873) 35-54 $\mu \mathrm{m}$ long, 21-30 $\mu \mathrm{m}$ wide, 14-20 $\mu \mathrm{m}$ thick, variable cell shapes. Cells flattened in dorso-ventral plane, often twisted. In ventral view, apices notched, with a nose-like protrusion. In lateral view, antapices dorsal reflex. One massive plastid. Species differs from others of the genus by the order of the nucleotides in nuclear ITS2, LSU and SSU rDNA gene sequences. Holotype: a large drop of unfixed dried cells of the strain VN873 on watercolour paper (hic designatus), deposited at MHA (Herbarium, Main Botanical Garden, Botanicheskaya Str. 4, Moscow, 127276, Russia) under the designation Cryptomonas vietnamica Vietnam Gusev 20-1 MHA, strain VN873.

Type strain: Representative living strain VN873 and DNA sample maintained at the Laboratory of Molecular Systematics of Aquatic Plants, IPPAS. The strain is also conserved as a formaldehyde-fixed sample.

Representative DNA sequences for VN873: GenBank accession numbers MT216866 (nuclear ITS2 and partial nuclear LSU rDNA), and MT216859 (nuclear SSU rDNA). Type locality: An old irrigation pond, Cat Tien National Park, Dong Nai Province, Vietnam. Latitude/Longitude $11^{\circ} 24.386^{\prime} \mathrm{N}, 107^{\circ} 22.463^{\prime} \mathrm{E}$, collected by E.S. Gusev in 2015.

Habitat: plankton

Etymology: The species name derived from "Vietnam", country from which this taxon was described.

Other representative cultures: VN874, VN877, VN880, VN881 and VN882. GenBank accession numbers see in Table 1.

Geographical distribution: To date, Cryptomonas vietnamica has been observed in six localities in Vietnam (Table 1). The new species was found in acidic to slightly acidic conditions ( $\mathrm{pH}$ from 5.2 to 6.7 ) with a specific conductance range of $11-127 \mu \mathrm{S} . \mathrm{cm}^{-1}$, and temperature 29-35 ${ }^{\circ} \mathrm{C}$ (Table 1$)$.

New record for Cryptomonas lundii. C. lundii is reported for the first time from Russia (Figs 8-9). This species was found in a peat bog in Meshchyora National Park, Vladimirskaya oblast $\left(55^{\circ} 35.077^{\prime} \mathrm{N} 40^{\circ} 26.485^{\prime} \mathrm{E}\right)$, with $\mathrm{pH}$ of 6.3 , specific conductance of $42 \mu \mathrm{S} . \mathrm{cm}^{-1}$, and temperature of $4.2{ }^{\circ} \mathrm{C}$.

\section{Discussion}

Cryptomonas lundii was described from a pond in Cologne (Germany) by HoEF-EMden \& MelKonian (2003), and previously known only from this habitat. A similar morphotype was previously reported by Lund from the British Isles (HoEF-EMDEN \& MELKONIAN 2003). One more sequence of partial LSU rDNA (strain 
M2587, GenBank accession number HE820910, not included in analysis due to the absence of nuclear SSU rDNA sequences) attributed to $C$. lundii is available in GenBank. But it is not identical to the sequence of $C$. lundii and represents a separate branch in the clade on the phylogenetic tree. Thus, our finding of this taxon is the second confirmed by molecular data, and the first report of $C$. lundii in Russia.

Molecular data confirm separation of Cryptomonas vietnamica and $C$. lundii both on the SSU and LSU rDNA phylogeny (Fig. 10) and secondary structure of the ITS2 molecule (Fig. 11). The CBC concept was previously used for species delimitation in the genus Cryptomonas
(Hoef-Emden 2007). The CBC species concept states that two organisms/strains whose ITS2 sequences differ by even a single $\mathrm{CBC}$ in the conserved regions of Helix II and Helix III represent two different biological species (Coleman 2000). According to Müller et al. (2007) and WoLF et al. (2013), the presence of any CBC in the whole ITS2 molecule is sufficient for distinguishing species. Cryptomonas vietnamica have five CBCs in the whole ITS2 molecule comparing to $C$. lundii in helices I, II and III (Fig. 11).

The strains from Vietnam clearly differ in morphology from cells of $C$. lundii. All strains represent cells with campylomorh-like morphotypes. Cells of
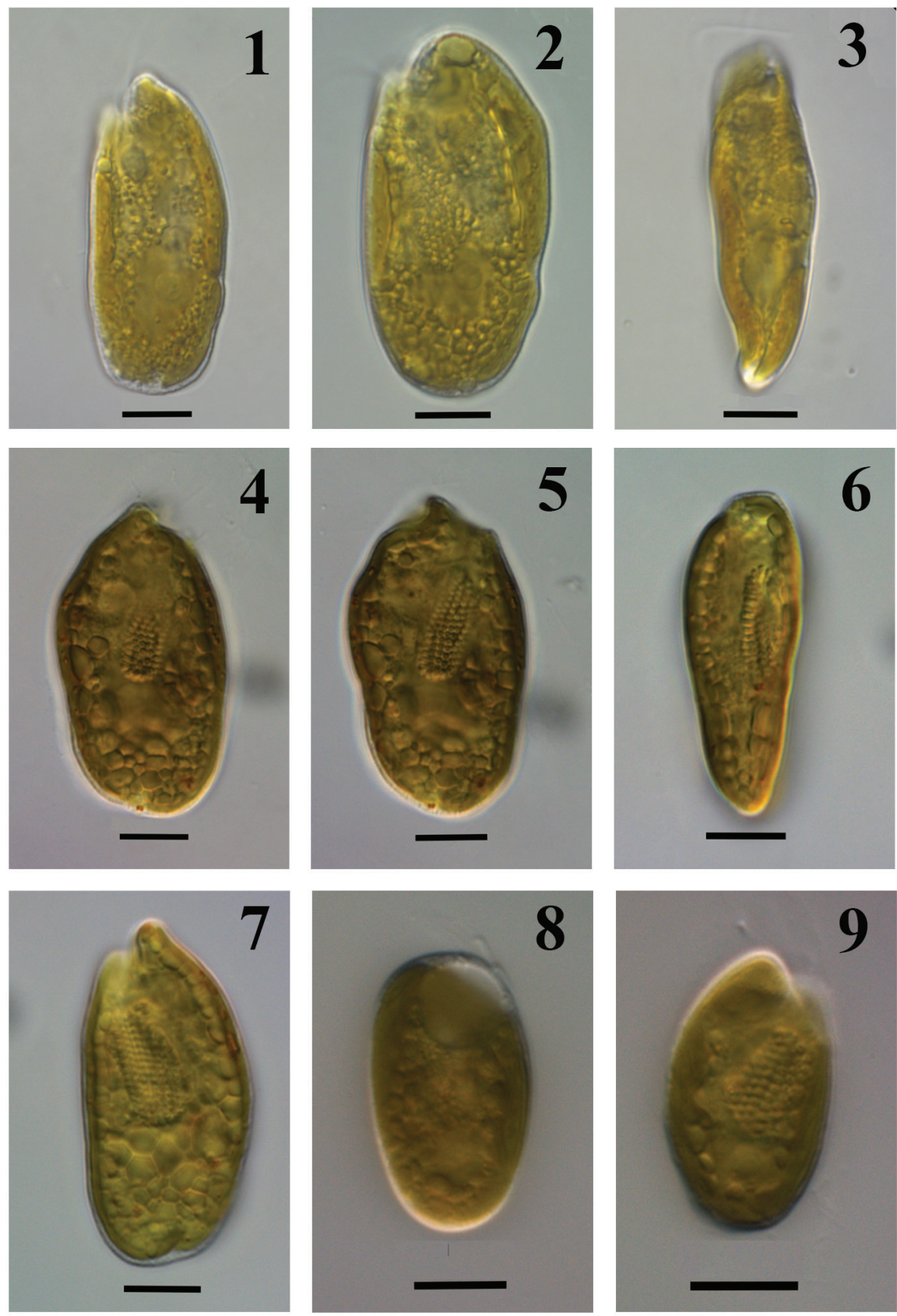

Figs 1-7. Light micrographs of Cryptomonas vietnamica sp. nov.: (1-3) light micrographs of the type strain VN873, (1-2) ventral view, (3) lateral view (left side); (4-7) light micrographs of the strain VN881, (4-5, 7) ventral view, (6) lateral view (right side).

Figs 8-9. Light micrographs of Cryptomonas lundii (strain R179): (8) dorsal view; (9) lateral view (right side). Scale bar $10 \mu \mathrm{m}$. 
the new species are larger, 35-54 × 16-30 × 13-20 $\mu \mathrm{m}$ (based on measurements of all strains of $C$. vietnamica) instead of $19-30 \times 12-16 \times 11-15 \mu \mathrm{m}$ in $C$. lundii. The shape and sizes of $C$. vietnamica cells are more similar to campylomorphs of Cryptomonas curvata Ehrenberg emend. Hoef-Emden et Melkonian, which is in a different clade on the phylogenetic tree. Among taxa not revised with molecular data, the most morphologically similar species is Cryptomonas platyuris Skuja, described from Sweden (SKUJA 1948). It has large cells, 31-50 $\times$ 15-24 × 9-14 $\mu \mathrm{m}$. It differs from $C$. vietnamica by the presence of a convex lateral edge and a sigmoid cell shape in broader view. Moreover, it was described in areas with a cold climate and has a northern distribution. Strains of Cryptomonas vietnamica were isolated in various, fairly remote areas of Vietnam, which may indicate the wide distribution of this taxon.

Up to now, only five taxa of the genus Cryptomonas were reported from Vietnam: C. erosa Ehrenberg, $C$. commutata (Pascher) Hoef-Emden (as Cryptochrysis commutata Pascher), C. ovata Ehrenberg, C. paramaecium (Ehrenberg) Hoef-Emden et Melkonian (as Chilomonas paramaecium Ehrenberg), and C. curvata Ehrenberg (Shirota 1966; Le Trong CuC 2001; DANG et al. 2002). All were identified in fixed samples during phytoplankton studies and lack illustrations and molecular data. There is no doubt that the real diversity of species of the genus Cryptomonas, as well as that of other cryptomonads, is much higher in Vietnam.

\section{ACKNOWLEDGEMENTS}

The authors are grateful to P. Kulizin for help in preparing images and to Tran Duc Dien and Phan Trong Huan for collection assistance. The authors are grateful to the staff of the Russia-Vietnam Tropical Centre for technical assistance. Sampling in Vietnam was conducted as part of the project "Ecolan 3.2" of the Russia-Vietnam Tropical Centre. Authors are grateful for reviewers for constructive comments which help to improve the manuscript. This study was supported by RFBR grant No. 18-04-01280_a.

\section{REFERENCES}

Andersen, R.A. (ed) (2005): Algal Culturing Techniques. 596 pp., Elsevier Academic Press, Oxford.

Boenigk, J.; Wodniok, S.; Bock, C.; Beisser, D.; Hempel,

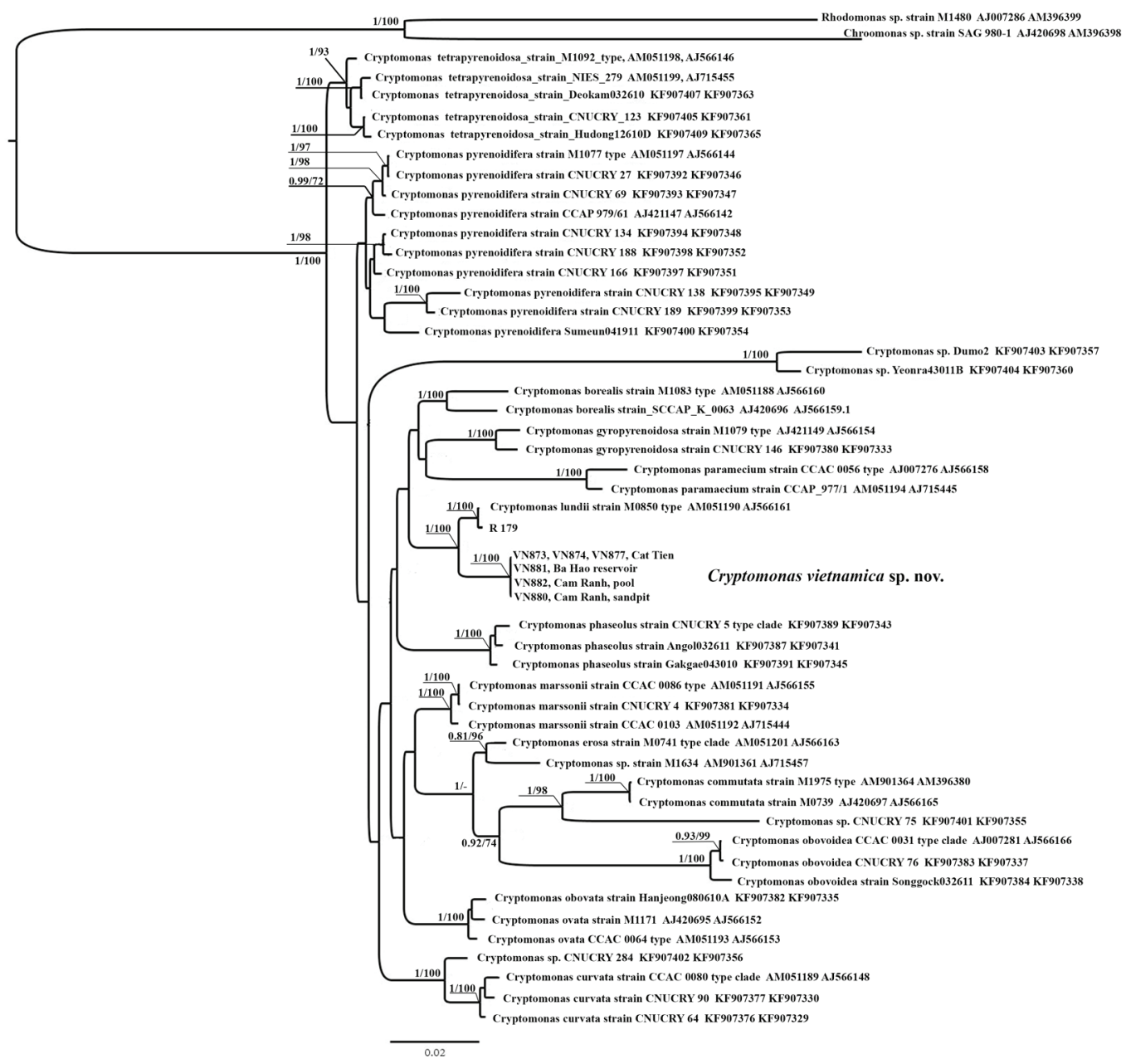

Fig. 10. Bayesian tree of the partial small subunit nuclear DNA (SSU rDNA) and large subunit nuclear DNA (LSU rDNA) combined data set. The Bayesian posterior probability and maximum likelihood bootstrap value are shown left and right of the fraction line respectively. Cryptomonas vietnamica sp. nov. is highlighted in bold. Scale bar represents: substitution per site. 


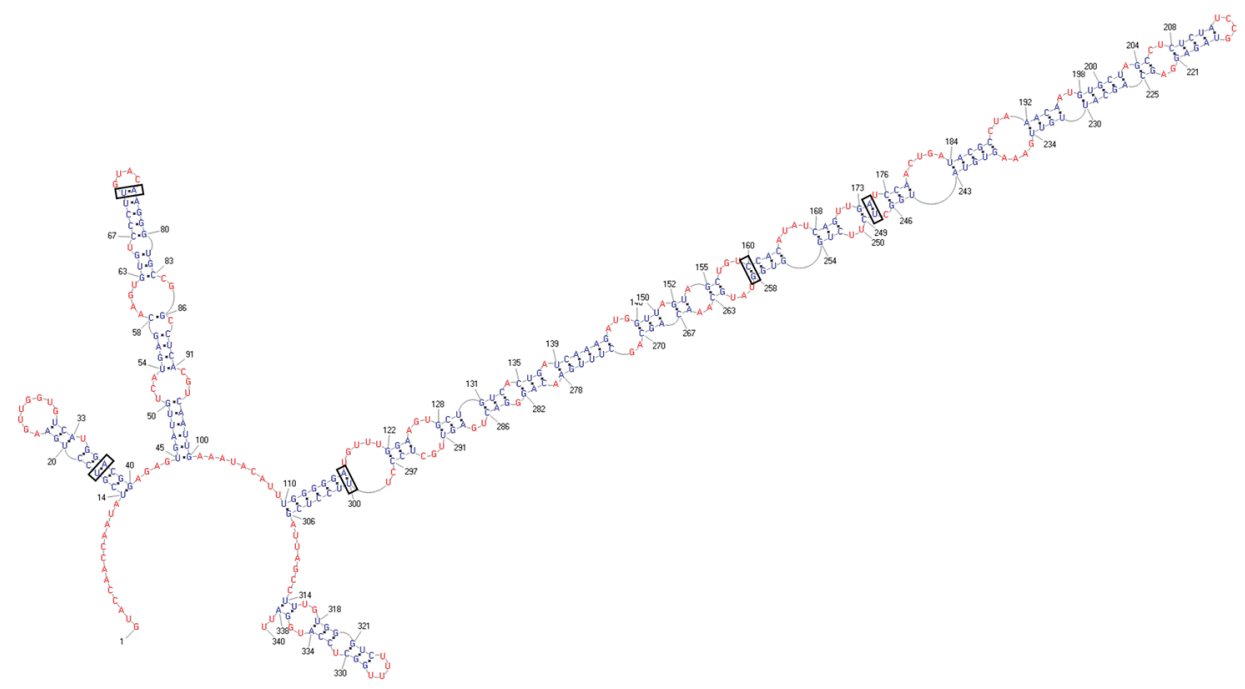

Fig. 11. Predicted secondary structure of the nuclear internal transcribed spacer 2 of Cryptomonas vietnamica (strain VN873). Black rectangular boxes - positions of Compensatory Base Changes (CBC) between Cryptomonas vietnamica and Cryptomonas lundii (strain R179).

C.; Grossmann, L.; Lange, A. \& Jensen, M. (2018): Geographic distance and mountain ranges structure freshwater protist communities on a European scale. - Metabarcoding and Metagenomics 2: e21519.

Cerino, F. \& Zingone, A. (2006): A survey of cryptomonad diversity and seasonality at a coastal Mediterranean site. - European Journal of Phycology 41: 363-378, DOI: $10.1080 / 09670260600839450$

ChoI, B.; Son, M.; KIM, J.I. \& ShIN, W. (2013): Taxonomy and phylogeny of the genus Cryptomonas (Cryptophyceae, Cryptophyta) from Korea. - Algae 28: 307-330. https:// doi.org/10.4490/algae.2013.28.4.307

Coleman, A.W. (2000): The significance of a coincidence between evolutionary landmarks found in mating affinity and a DNA sequence. - Protist 151: 1-9. DOI: $10.1078 / 1434-4610-00002$

DANG, N.T.; Ho, T.H.; DuONG, D.T. \& MaY, D.Y. (2002): Hydrobiology in inland freshwaters of Vietnam. 399 pp., Science and Technique Publisher, Hanoi (in Vietnam).

EHRENBERG, C.G. (1831): Symbolae physicae seu icones et descriptiones animalium evertebratorum sepositis insectis quae ex itinere per Africanum Borealem et Asiam Occidentalem Frideric iGuilelmi Hemprich et Christiani Godofredi Ehrenberg medicinae et chirurgiae doctorum studio novae aut illustratae redierunt. - 149 pp., Berlin, Mittler.

Hoef-Emden, K. (2007): Revision of the genus Cryptomonas (Cryptophyceae) II: Incongruences between classical morphospecies concept and molecular phylogeny in smaller pyrenoid-less cells. - Phycologia 46: 402-428. DOI: https://doi.org/10.2216/06-83.1

Hoef-Emden, K. \& Archibald, J.M. (2016): Cryptophyta (Cryptomonads). - In: ARChibald, J.M.; Simpson, A.G.B.; Slamovits, C.H.; Margulis, L.; Melkonian, M.; Chapman, D.J. \& Corliss, J.O. (eds): Handbook of the Protists. $-41 \mathrm{pp}$. Springer International Publishing, Cham, Switzerland. DOI: https://doi. org/10.1007/978-3-319-28149-0 35

Hoef-Emden, K. \& Melkonian, M. (2003): Revision of the genus Cryptomonas (Cryptophyceae): A combination of molecular phylogeny and morphology provides insights into a long-hidden dimorphism. - Protist 154: 371-409. DOI: https://doi.org/10.1078/143446103322454130

KatoH, K. \& Tон, H. (2010): Parallelization of the MAFFT multiple sequence alignment program. - Bioinformatics 26: 1899-900. DOI: http://dx.doi.org/10.1093/ bioinformatics/btq224

Kumar, S.; Stecher, G.; Li, M.; Knyaz, C. \& Tamura, K. (2018): MEGA X: Molecular Evolutionary Genetics Analysis across computing platforms. - Molecular Biology and Evolution 35: 1547-1549. DOI: http:// dx.doi.org $/ 10.1093 / \mathrm{molbev} / \mathrm{msy} 096$

Lane, C.E. \& ArChibald, J.M. (2008): New marine members of the genus Hemiselmis (Cryptomonadales, Cryptophyceae). - Journal of Phycology 44: 439-450. DOI: https://doi.org/10.1111/j.1529-8817.2008.00486.x

Le Trong CuC (2001): Checklist of plant species of Vietnam. Part 1. - 1182 pp., Hanoi (in Vietnam).

McFadden, G.I. \& Melkonian, M. (1986): Use of Hepes buffer for microalgal culture media and fixation for electron microscopy. - Phycologia 25: 551-557. DOI: https:// doi.org/10.2216/i0031-8884-25-4-551.1

Müller, T.; PhilipPi, N.; Dandekar, T.; Schultz, J. \& WOLF, M. (2007): Distinguishing species. - RNA 13: 1469-1472. DOI: 10.1261/rna.617107

Posada, D. (2006): Modeltest Server: a web-based tool for the statistical selection of models of nucleotide substitution online. - Nucleic Acids Research 34: 700-703. DOI: http://dx.doi.org/10.1093/nar/gk1042

Ronquist, F. \& HuelsenBeCK, J.P. (2003): MrBayes 3: Bayesian phylogenetic inference under mixed models. - Bioinformatics 19: 1572-1574. DOI: http://dx.doi. org/10.1093/bioinformatics/btg180

Seibel, P.N.; Müller, T.; Dandekar, T. \& Wolf, M. (2008): Synchronous visual analysis and editing of RNA sequence and secondary structure alignments using 4SALE. - BMC Research Notes 1: 91. DOI: 10.1186/1756-0500-1-91

Shalchian-Tabrizi, K.; Brate, J.; Logares, R.; Klaveness, D.; BERNEY, C. \& JAKOBSEN, K.S. (2008): Diversification of unicellular eukaryotes: Cryptomonad colonizations of marine and fresh waters inferred from revised 18S rRNA phylogeny. - Environmental Microbiology 10: 2635-2644. 
DOI: http://dx.doi.org/10.1111/j.1462-2920.2008.01685.x SkujA, H. (1948): Taxonomie des Phytoplankton seiniger Seen in Uppland, Schweden. - Symbolae Botanicae Upsaliensis 9: 1-399.

Shirota, A. (1966): The plankton of South Viet-Nam. - 462 pp., Fresh Water and Marine Plankton. Overseas Technical Cooperation Agency, Japan.

Xia Shuang, Liu Guo-Xiang, Hu Zheng-Yu (2013): Morphological examination and phylogenetic position of two newly recorded freshwater Cryptomonas species (Cryptophyceae) from China. - Journal of Systematics and Evolution 51: 212-222. DOI: 10.1111/j.1759-6831.2012.00227.x

von der Heyden, S., Chao, E. E., \& CAVAlier-Smith, T. (2004):
Genetic diversity of goniomonads: An ancient divergence between marine and freshwater species. - European Journal of Phycology, 39: 343-350. DOI:https://doi. org/10.1080/09670260400005567

Wolf, M.; Chen, S.; Song, J.; Ankenbrand, M. \& Müller, T. (2013): Compensatory Base Changes in ITS2 Secondary Structures Correlate with the Biological Species Concept Despite Intragenomic Variability in ITS2 Sequences - A Proof of Concept. - PLoS ONE 8: e66726. DOI: 10.1371/journal.pone.0066726

ZuKer, M. (2003): Mfold web server for nucleic acid folding and hybridization prediction. - Nucleic Acids Research 31: 3406-3415. DOI: 10.1093/nar/gkg595

(C) Czech Phycological Society (2020)

Received January 21, 2020

Accepted April 28, 2020 